\title{
Brain Capability Identification: An Expert System for Children in Elementary School
}

\author{
Arif Hidayat ${ }^{1 *}$

\begin{abstract}
${ }^{1}$ Fakultas Ilmu Komputer, Universitas Muhammadiyah Metro, Metro 34381, Indonesia
*Corresponding author. Email: androidarifhidayat@gmail.com
\end{abstract}

\begin{abstract}
This study aims to determine the ability of the brain in elementary school children. This type of research is experimental research. This application user is a class teacher once an Elementary school student facilitator. It is very natural for teachers to want their students to grow up to be healthy, intelligent, clear-minded, and noble children. Classroom learning by the teacher is like a thought process or in other words, is the process of using and using the brain optimally. The human brain consists of two parts, the right brain, and the left brain. Each hemisphere has specialized in certain abilities. The thinking process of the left brain is logical, sequential, linear, and rational. This side is very regular. Although based on reality, the left brain is able to carry out abstract and symbolic interpretations. The way of thinking is appropriate for regular tasks of verbal expression, writing, reading, auditory associations, placing details and facts, phonetics, and symbolic. Besides the information generated can be used as an alternative expert (teacher) in consulting about the identification of students 'brain abilities in elementary school children which includes indications, students' brain abilities, causes, and solutions.
\end{abstract}

Keywords: children, brain capability, elementary school

\section{INTRODUCTION}

In neurobiological, the human brain consists of billions of nerve cells or neurons that spread across the entire human brain. As stated by a neurologist, Gerald Edelman, Nobel Prize winner, needed more than 32 million years to count all synapses in the human brain with a speed of one synapse per second [1]. If you focus on the possibility of the number of nerve connections in the brain, then there is a very amazing number of 10 followed by a million zeros. Each nerve of the brain is interconnected and communicates through one or more relationships. However, every nerve in the brain has the responsibility and function of each. For example, reading activities activate the occipital and frontal areas. Listening to music with closed eyes activates the temporal, frontal and cerebellar areas. In addition, broadly speaking, brain humans are divided into the workings of the brain hemisphere left and right, but the work activities of the two brains are not separate. The activities of the two brains are joined together and also build each other.

The human brain consists of the left and right hemispheres. Left brain or left cerebral hemisphere relating to academic functions which consist of speaking ability, ability to process grammar, reading and writing, memory (names, times and events), logic, numbers, analysis, and so on. While the right brain or right cerebral hemisphere a place for the development of things that are artistic, creativity, feelings, emotions, style of language, the rhythm of music, imagination, imagination, colour, self, and others, socialization, personality development. Many experts say the left-brain controls IQ (Intelligence Quotient), while the right brain plays an important role in the development of one's EI (Emotional Intelligence).

Teachers in carrying out learning at school should know and understand that the importance of using both brains to learn. Learning becomes easy if the teacher can balance the two brain functions in the learning process. The right brain is as creativity and imagination and is also a non-linguistic factor that can give ideas to the left brain in giving birth to words and language. Creativity and imagination are very important in the process of language learning. Creativity and imagination need to be developed. If creativity is developed in the learning process, then learning will be a fun process for students. The implication is that students will form creative learning patterns that are not dependent on others. This will make students more prepared and able to adjust to all changes and demands that occur in their environment.

Several studies conducted regarding the identification of brain abilities are titled "Identification of Critical Thinking Ability of Grade X Students in terms of initial ability and gender of students in SMK 1 Kamal"[2]. The purpose of this study was to identify students 'critical thinking skills in terms of the students' initial abilities and gender. Critical thinking used is an indicator of critical thinking according to Facione. In this study, initial abilities were categorized into 2, namely a) high initial ability; and b) Low Initial Ability. To get the initial ability group, the Early ability test was conducted, then in each category were grouped again by sex and obtained 4 students.

Another second study refers to the problem of brain abilities titled "Analysis of Characteristics of Student Learning Styles in Economics Class XI IPS"[3]. This study aims to describe the characteristics of student learning styles which consist of characteristics of vak learning styles and their 
tendency to understand economic lessons. The subjects of this study were students of class XI IPS when learning economics. This research is a descriptive study with a qualitative approach. The results of the study showed that the characteristics of students' learning styles in Economics subjects in class XI IPS were a combination of characteristics of vak learning styles.

Another third study refers to the problem of brain abilities titled "Identification of Students' Mathematical Creative Thinking Ability in Variable Linear One Equation Class VII MTS N 5 Magelang" [4]. This study aims to describe the identification of students' mathematical creative thinking skills. The creative aspects of the brain can help explain abstract concepts, allowing students to achieve greater mastery, especially in learning mathematics and science. Based on the results of previous research on the identification of brain abilities in students as described above, further research is carried out under the title "Brain Capability Identification: An Expert System for Children in
Elementary School". The problem formulation of this study is how to implement an expert system as a means of identifying brain abilities in elementary school children, while the goal to be achieved is to implement an expert system as a means of identifying brain abilities in elementary school children.

\section{METHOD}

The method used in this study refers to the software development process namely with the Waterfall Model/Linear Sequential Model [5]. Emphasis is made and starts from the analysis, design, code and testing of the system. The advantage of the Waterfall Model is that the process is more structured, this makes the quality of the software good and maintained.

Table 1 Identification opportunities with SWOT

\begin{tabular}{|c|c|c|}
\hline \multirow[b]{2}{*}{ EXTERNAL FACTORS } & Strength (S) & Weakness (W) \\
\hline & $\begin{array}{l}\text { 1. There is desire from Party } \\
\text { School Basic for apply } \\
\text { technology system expert as tool } \\
\text { identification ability brain on } \\
\text { child school basic } \\
\text { 2. There is amenities and source } \\
\text { powver for implement technology } \\
\text { system expert as tool } \\
\text { identification ability brain on } \\
\text { child school basic }\end{array}$ & $\begin{array}{l}\text { 1. The absence of technology } \\
\text { system expert as tool } \\
\text { identification ability brain on } \\
\text { child school basic } \\
\text { 2. Still use it the way manual } \\
\text { identification by writing one by } \\
\text { one the results of the analysis of } \\
\text { students' brain abilities. }\end{array}$ \\
\hline Opportunity $(\mathrm{O})$ & Strategy (SO) & Strategy (WV-0) \\
\hline $\begin{array}{l}\text { 1. If it is technology system } \\
\text { expert as tool identification } \\
\text { ability brain on child school } \\
\text { basic then the user could do } \\
\text { identification } \\
\text { to students who are } \\
\text { accompanied by facilitator } \\
\text { 2. Progress technology that can } \\
\text { made as solution problem in } \\
\text { thing identification ability } \\
\text { brain students, as well learning } \\
\text { system technology this could } \\
\text { make it as tool tool } \\
\text { identification ability brain on } \\
\text { child school basic }\end{array}$ & $\begin{array}{l}\text { 1. Realize desire party school basic } \\
\text { for apply system expert as tool } \\
\text { identification ability brain. } \\
\text { 2. Make use of amenities and } \\
\text { source power for implement } \\
\text { technology system expert as tool } \\
\text { identification ability brain on } \\
\text { child school basic }\end{array}$ & $\begin{array}{l}\text { 1. Make it and Implement it } \\
\text { technology system expert as tool } \\
\text { identification ability brain on } \\
\text { child school basic. } \\
\text { 2. Implement it system } \\
\text { management expert if party } \\
\text { school do identification ability } \\
\text { brain on child school basic. }\end{array}$ \\
\hline Threat (T) & Strategy (ST) & Strategy (WT) \\
\hline $\begin{array}{l}\text { 1. The attack is indeed have } \\
\text { intention evil for damage } \\
\text { system expert as tool } \\
\text { identification ability brain on } \\
\text { child school basic. } \\
\text { 2. System expert identification } \\
\text { ability brain on child can only } \\
\text { happen error without diduga- } \\
\text { suspect }\end{array}$ & $\begin{array}{l}\text { 1. Apply configuration security on } \\
\text { System expert identification } \\
\text { ability brain on child. } \\
\text { 2. Apply management backup on } \\
\text { system expert identification } \\
\text { ability brain on child school } \\
\text { basic }\end{array}$ & $\begin{array}{l}\text { 1. Make it and Implement it system } \\
\text { management expert with look } \\
\text { aspect security } \\
\text { 2. Assure confidence user / agency } \\
\text { especially school basic so as not } \\
\text { blocking implemented yes } \\
\text { system expert identification } \\
\text { ability brain on child }\end{array}$ \\
\hline
\end{tabular}

\section{RESULTS AND DISCUSSION}

\subsection{Analysis}

In the discussion phase then begins by analysing Brain Capability Identification: An Expert System for Children in Elementary School use SWOT (strengths, weaknesses, opportunities, threats) Analysis. SWOT Analysis is used to identify opportunities and be used as a quick tool in finding possibilities related to the initial development of new innovation programs and use your SWOT analysis to discover recommendations and strategies, with a focus on leveraging strengths and opportunities to overcome weaknesses and threats [6].

\subsection{Data Needs and System Requirements}

From the data collection that has been done by observation and interview process with the elementary school, obtained 40 data samples in the form of knowledge data about the 
conditions of the rule is true, specify all the stages that occur in the dialogue and decision. In a system using a forward chaining approach in the process of matching facts. The search graph matches the knowledge base by using the forward chaining method.

\subsection{System Planning}

System design is a description of the system to be built. Measures to assist the identification of brain power of children is realized with the dialogue between user and the system in the form of options that have been stored in the system to produce an output in the form of a diagnosis of the brain's ability students, the causes and solutions associated with the brain's ability in elementary school students.

\subsubsection{Process modelling}

\subsubsection{Context diagram}

Context Diagram is a diagram that describes the flow of data in an outline. This diagram records the data that enters the system and its sources and the information generated by the system and its purpose.

The inference is a process to produce information from contents of a list of rules based on the sequence or pattern. Sela $\mathrm{m}$ diagnosis processes between system and user, the inference engine testing rules one by one until the

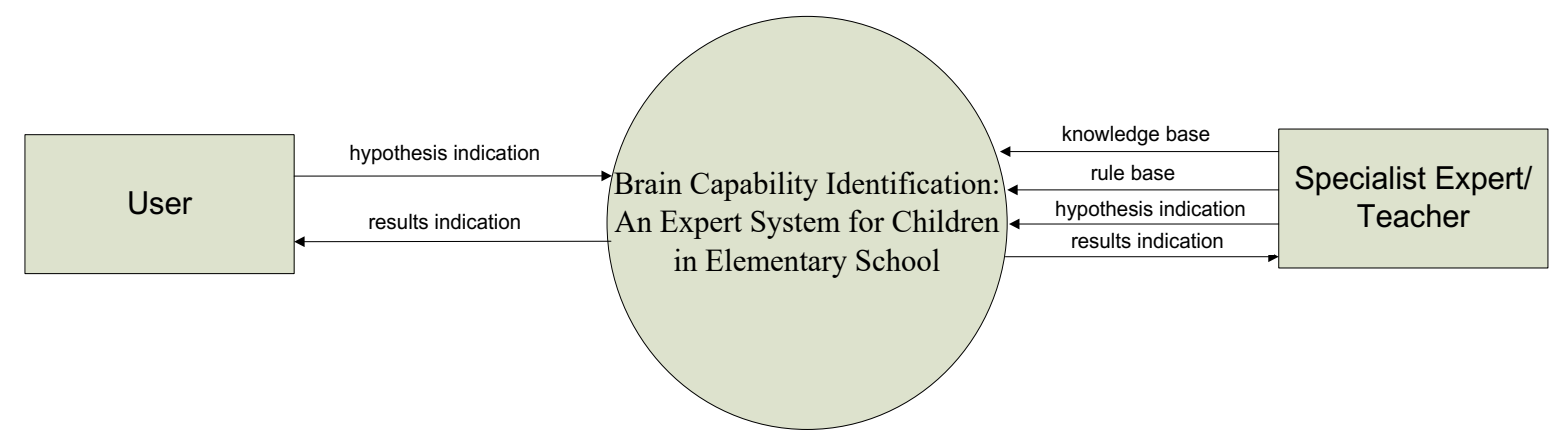

Figure 1 Data Flow Diagram (DFD) Level 0

\subsubsection{DFD level 1}

In designing data flow diagrams there are ten processes, namely managing the knowledge base which includes managing indications, managing students 'brain abilities, managing causes, managing experts, managing solutions, managing rules, displaying questions, determining indications, accommodating diagnoses, displaying diagnostic results of students' brain abilities.

\subsubsection{Data modelling}

\subsubsection{Entity relationship diagram}

And the results of the analysis, used be the data that will be used in the process development of expert system applications as an identification tool for students' brain abilities based on responsive website applications that can be accessed by smartphones. Then and the data that has been obtained, a base design is built data using models Entity Relational Diagram (ERD). 


\subsubsection{Mapping table}

At this stage, the mapping table is used to process table mapping from the conceptual data model or ERD to physical data that is more intended to find out the truth or validity of the relationships between entities that have been made in the existing case studies.

\subsubsection{Database}

After going through the ERD design stage, then to implement this application it takes several tables or entities along with their attributes or fields. This is used to collect and store data or knowledge of damage as system requirements are made.

\subsection{Interface Design}

System menu design is the design stage to access menus used in this expert system application. Figure draft explains that the structure of the expert system application program as a means of identification of brainpower on elementary school children which consists of the main menu screen in which there are menu selection. And then data entry is carried out in this system through forms that become the interface between the user and the system. Be included in one example of a draft form for the menu main page before logging in.

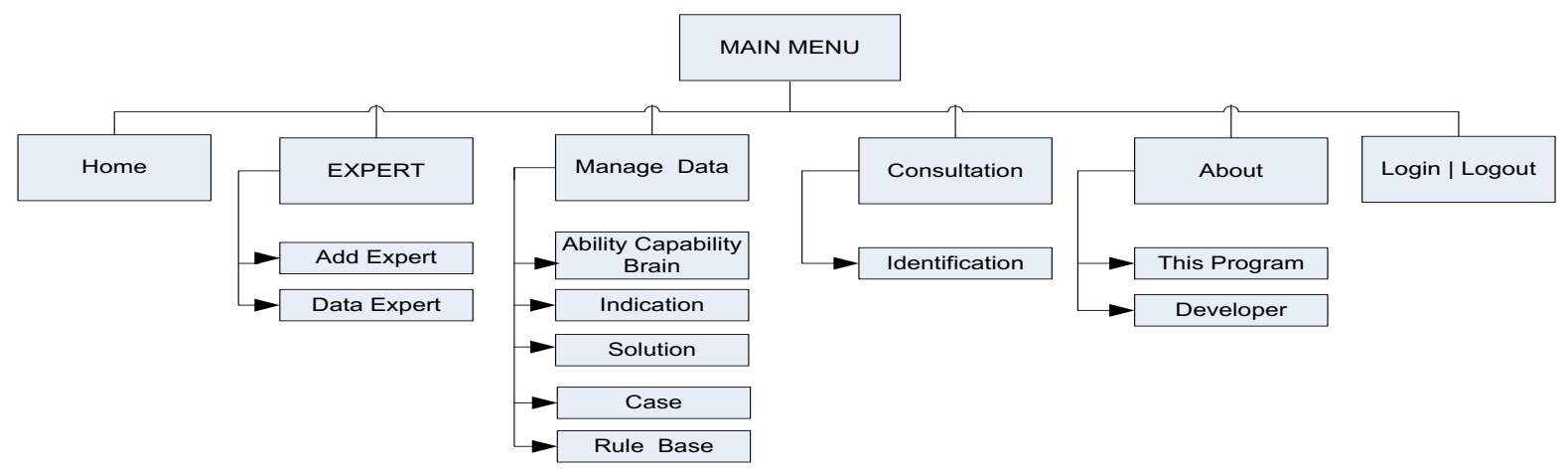

Figure 2 Menu Design

\subsection{Implementation}

Expert System Implementation Application As A Brain Ability Identification Tool For Elementary School Children created using the Adobe Dreamweaver application with the
MySql database. Implementation focuses on Program Main Menu, Rule Base Input Form, Consultation Menu Form and Consultation Result Form. Display the main menu when the program is run, before the expert does log in. The rule-based input is used to enter relationships from the data that has been entered. The relationship between indication data, student brain ability data, data causes, expert data, data rules and data solutions stored in the database.

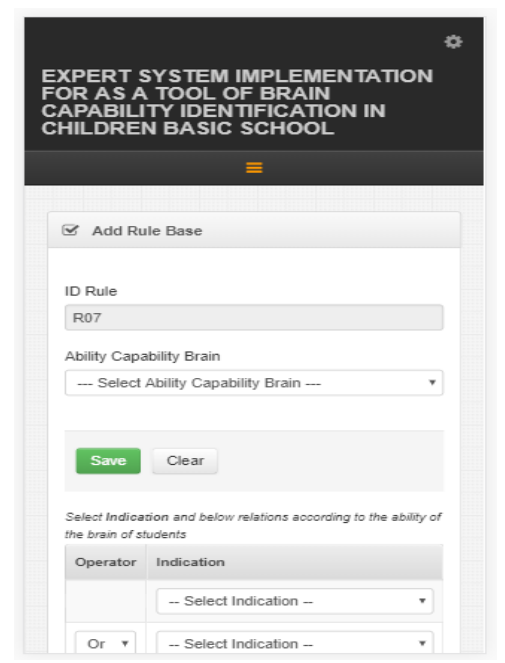

Figure 3 Rule Base Input Form Display

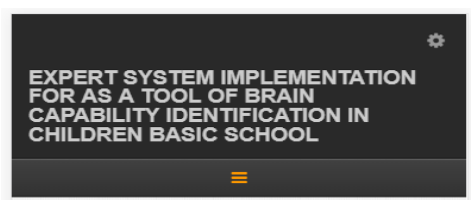

$\checkmark$ BRAIN CAPABILITY IDENTIFICATION

Process Of Brain Capability

Identification in Children Basic School

G001 $\Rightarrow$ Do you often look up and looks like daydreaming?

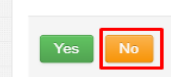

Copyright 2018 Arit Hit

Figure 4 Display Consultation Menu
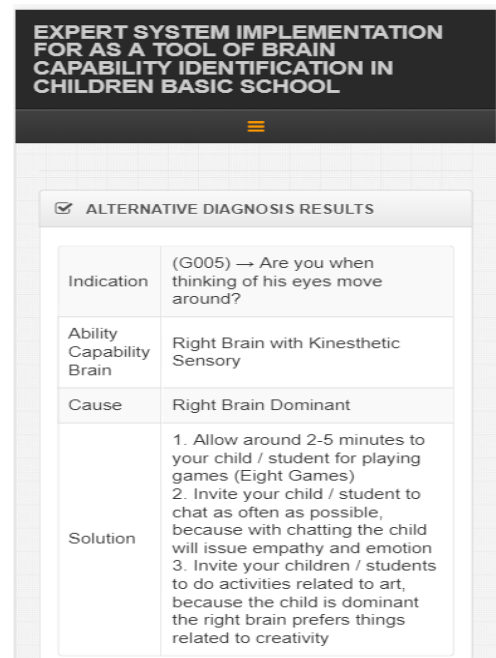

Figure 5 Display of Consultation Results 
On example of the consultation case above the user only choose the answer [yes] to one of the questions with the symptom code G001, G002, G005, the results of the system calculation indicate that the student at the time of thinking his eyes is moving. Therefore, the student has the ability of the brain " Right Brain with Kinaesthetic Sensory" which means that students end up just quiet, keep moving, moving irregularly, often doing things that are full of risk, good at making something of his hand work. This can be dissolved by 1) giving around 2-5 minutes to your child/ student for playing games (Eight Games), 2) inviting your children/students to chat as often as possible, because by chatting children will emit a sense of empathy and emotion, 3 ) invite your children / students to do activities related to art, because children with right brain are more likes things related to creativity.

\subsection{Testing}

The last stage in network design is testing. This test is conducted to test and find out whether the expert system Identifies Brain Ability in Elementary School Children going well and correctly as expected by the school. This expert system uses two types of testing, namely:

\subsubsection{Black box test}

This test involves several people, two leading experts from elementary school School 3 Sumbersari East Lampung, and 38 teachers of SDN 1, SDN 2, SDN 3 Sumbersari, East Lampung Indonesia as an expert system application user for identification of the brain's ability students in elementary school children.

Table 2 Black Box Test Questions

\begin{tabular}{|c|c|c|c|}
\hline No & Question & Y (yes) & T (no) \\
\hline 1. & Input data indication, a student's brain ability, causes, and solutions are correct? & 40 & 0 \\
\hline 2. & Rule based input is running correctly? & 40 & 0 \\
\hline 3. & $\begin{array}{l}\text { Is the process of tracking students' brain abilities on the consultation menu or diagnosis } \\
\text { going well? }\end{array}$ & 40 & 0 \\
\hline 4. & Does the output of the ability of the student's brain to produce the diagnosis match? & 40 & 0 \\
\hline 5. & Are the causal outputs and solutions to the diagnosis results suitable? & 40 & 0 \\
\hline 6. & Can the system work properly? & 40 & 0 \\
\hline \multicolumn{2}{|c|}{ Total } & 240 & 0 \\
\hline
\end{tabular}

Based on the above results obtained presenting an assessment of the application system is, Yes $=240 / 240 \mathrm{x}$ $100 \%=100 \%$, No $=0 / 240 \times 100 \%=0 \%$. The presentation of the test results can be concluded that the system is suitable for use in wheezing identification brain's ability students in elementary school children.
This test conducted by 25 students Sumbersari 1 Public Elementary School East Lampung Indonesia and questioner This is awarded after students that is to try to use expert system application in order to wheeze identification brainpower student on elementary school children as well as at the time of use accompanied by the class teacher.

\subsubsection{Alfa test}

Table 3 Alpha Test Questions

\begin{tabular}{|l|l|c|c|c|c|}
\hline \multirow{2}{*}{ No Question } & \multicolumn{3}{|c|}{ Assessment } \\
\cline { 3 - 6 } & & SS & S & KS & TS \\
\hline 1. & This expert system application can be operated easily & 8 & 17 & - & - \\
\hline 2. & Interesting program appearance & 12 & 13 & - & - \\
\hline 3. & Identification process of students' brain abilities is easy to do & 13 & 12 & - & - \\
\hline 4. & Identification results are easy to understand & 9 & 16 & - & - \\
\hline 5. & The expert system application when executed does not occur an error & 1 & 24 & - & - \\
\hline 6. & This expert system application can help make decisions & 19 & 6 & - & - \\
\hline 7. & This expert system application has benefits for users & 15 & 10 & - & - \\
\hline \multicolumn{2}{|c|}{ Total } & $\mathbf{7 7}$ & $\mathbf{9 8}$ & - & - \\
\hline
\end{tabular}

Based on the test results, it can be obtained the percentage of assessment of the expert system application system, namely: a) Answer SS/Strongly Agree $=44 \%$ $\left(77 / 175^{*} 100 \%\right)$, b) Answer $\mathrm{S}$ /agree $=56 \%$ $\left(98 / 175^{*} 100 \%\right)$, Answer KS/not agree $=0 \%$ and Answer TS $($ disagree $)=0 \%$. From the results of an assessment of the system, it can be concluded that the system is suitable for use in the brain's ability to wheezing identification students in elementary school children.

\section{CONCLUSION}

Based on the results of research and discussion, it can be concluded that from the expert system research designed to be able to identify the brain abilities of students in elementary school children. In addition, based on the results of testing the software has identified the ability of the brain of students in elementary school children according to the 
[11] Hidayat, A., Muslihudin, M., \& Utami, I. T. SistemPendukung Keputusan Menentukan Lokasi Cafe Baru Suncafe Sebagai Destinasi Wisata Kuliner Di Kabupaten Pringsewu Menggunakan Metode Simple Additive Weighting (SAW). Jurnal TAM (Technology Acceptance Model), 6, 71-79.2017.

[1] R. Restak, The New Brain. London: Rodale Publishing, 2004, 5.

[2] Hayudiyani, Meila; Arif, Muchamad; Risnasari, Medika. IdentifikasiKemampuanBerpikirKritisSiswa Kelas X TkjDitinjau Dari KemampuanAwal Dan JenisKelaminSiswa di SMKN 1 Kamal. JurnalIlmiahEdutic, 2017, 4.1: 20-31.

[3] Ulfah, Maria, et al. AnalisisKarakteristik Gaya BelajarSiswa Pada Mata Pelajaran Ekonomi Kelas Xi IPS. Jurnal Pendidikan dan Pembelajaran, 2017, 6.1.

[4] Wahyuni, Ika; RATU, Novisita. IdentifikasiKemampuanBerpikirKreatifMatematisSiswa Pada MateriPersamaan Linear Satu Variabel Kelas Vii Mts N 5 Magelang. Pendekar: Jurnal Pendidikan Berkarakter, 2018, 1.1: 340-346.

[5] Pressman Ph.D., Roger S, RekayasaPerangkatLunak, CV Andi Offset, Yogyakarta. 2002.

[6] Chermack, Thomas J.; Kasshanna, Bernadette K. The use and misuse of SWOT analysis and implications. Human Resource Development International, 2007, 10.4: 383-399.

[7] Hidayat, A.

AplikasisistempakaruntukKebutuhanGiziIbuMenyusui. Jurnal TAM (Technology Acceptance Model), 2017, 5, 88-93.

[8] Kusrini, SistemPakarTeori Dan Aplikasi. CV Andi Offset, Yogyakarta, 2006.

[9] Kusumadewi, Sri., Artificial Intelligence, Graha Ilmu, Yogyakarta, 2003.

[10] Hidayat, A. Building a Expert System Application for Help Problem Solving Network on Mikrotik Router. Mikrotik: JurnalManajemenInformatika, 2017, 6(1).
[12] Giarratano, J. C., \& Riley, G. Expert systems. PWS publishing co.1998.

[13] Hart, A. Knowledge acquisition for expert systems. School of Computing, Lancashire Polytechnic, Preston. 1986.

[14] Krishnamoorthy, C. S., \& Rajeev, S. Artificial intelligence and expert systems for engineers. CRC press. 2018

[15] Klir, G. J. Architecture of systems problem solving. Springer Science \& Business Media.2013.

[16] Henard, C., Papadakis, M., Harman, M., Jia, Y., \& Le Traon, Y. Comparing white-box and black-box test prioritization. In 2016 IEEE/ACM 38th International Conference on Software Engineering (ICSE), 2016. (pp. 523-534). IEEE.

[17] Su, K. W., Liu, T. H., \& Hwang, S. L. A developed model of expert system interface (DMESI). Expert systems with Applications, 2001. 20(4), 337-346.

[18] Agarwal, M., \& Goel, S. Expert system and it's requirement engineering process. In International Conference on Recent Advances and Innovations in Engineering (ICRAIE-2014)(pp. 1-4). IEEE.

[19] Naqvi, S., Siddiqi, R., Hussain, S. A., Batool, H., \& Arshad, H. School children training for basic life support. J Coll Physicians Surg Pak, 2011. 21(10), 6115.

[20] Maconochie, I., Simpson, S., \& Bingham, B. Teaching children basic life support skills.2007.

[21] Prince, D. L., \& Howard, E. M. Children and their basic needs. Early Childhood Education Journal, 2002. 30(1), 27-31. 